\title{
Biochar from argan shells: production and characterization
}

\author{
Laila Bouqbis $^{1}$ - Salma Daoud ${ }^{2} \cdot$ Hans-Werner Koyro $^{3}$ - Claudia Irene Kammann ${ }^{3}$. \\ Lalla Fatima Zohra Ainlhout ${ }^{1} \cdot$ Moulay Cherif Harrouni ${ }^{4}$
}

Received: 10 March 2016/ Accepted: 14 November 2016/Published online: 18 November 2016

(c) The Author(s) 2016. This article is published with open access at Springerlink.com

\begin{abstract}
Purpose The agricultural practices in south western Morocco reserve a majority of the water resources to be used for irrigation. The extent of irrigated agriculture combined with high evaporative rates, lead to the depletion of water resources and degradation of soil quality. To remedy to this problem, biochar, a pyrolysed biomass, is highly considered to improve retaining water and nutrients in soils. For this biochar research, argan shells obtained after extraction of argan oil were used as the biomass source to produce biochar. According to the best of our knowledge, no research to date has been carried out on the production and characterization of biochar produced from argan shells wastes.

Methods To produce biochar, we have used a pyrolytic stove fabricated in Morocco from locally available materials. The biochar sample collected was then crushed, sieved $(<2 \mathrm{~mm})$ and its physical, and chemical characteristics were analysed and compared with those of other media (soil and peat).

Results The physical and chemical properties of the argan shells biochar revealed a highly alkaline $\mathrm{pH}$, high electrical conductivity, high content of $\mathrm{K}, \mathrm{Na}, \mathrm{Mg}$ and $\mathrm{NaNO}_{3}$, low
\end{abstract}

Laila Bouqbis

bouqbisl@yahoo.fr

1 Department of Sciences, Polydisciplinary Faculty, Ibn Zohr University, Taroudant, Morocco

2 Department of Biology, Faculty of Sciences, Ibn Zohr University, Agadir, Morocco

3 Department of Plant Ecology, Justus-Liebig-University, Heinrich-Buff-Ring 26-32, 35392 Giessen, Germany

4 Soil Science Laboratory, Hassan II Agronomic and Veterinary Institute, Agadir, Morocco content of $\mathrm{Ca}, \mathrm{KH}_{2} \mathrm{PO}_{4}$ and low content of heavy metals compared to sandy soil and peat. In addition, by increasing biochar application, the water holding capacities of biochar-sand mixtures also increased.

Conclusions The use of argan shells biochar to enrich the soil will be expected to improve both nutrient and water retention especially that South Western Morocco is subject to frequent drought.

Keywords Biochar Argan shells · Biochar analysis . Nutrients · Water retention

\section{Introduction}

In recent years, the practice of amending agricultural soils with bio-resources, biochar, has gained increasing attention. Biochar has been reported as a soil amendment for enhancing soil structure, increasing crop yields (Lehmann et al. 2006; Liu et al. 2012; Tammeorg et al. 2014), increasing microbial activity (Hossain et al. 2010; Jiang et al. 2016) and decreasing soil bulk density (Laird et al. 2010). Due to its positive effect on the physical, chemical and biological properties of soils, biochar indirectly helps improving crop productivity (Liu et al. 2013; Smider and Singh 2014; Kaudal et al. 2016). Yet, previous studies have shown that the biochar environmental function in soil changes depending on the physical and chemical properties of the biochar.

In the Mediterranean, semi-arid climatic conditions have led to a decrease in soil organic matter content (Romanyà and Rovira 2011). In such environmental conditions, the use of biochar can enhance soil structure, nutrients and water holding capacity (Kammann et al. 2011; Smider and Singh. 2014; Tammeorg et al. 2014; Cao et al. 2014; Stella Mary et al. 2016). 
Over two thirds of Morocco can be classified as semiarid, arid and desert with low and variable rainfalls. Resources are predominantly consumed by irrigated agriculture leading to the depletion of water resources and degradation of soil quality especially that south western Morocco is subject to frequent drought (Badraoui et al. 2000; Debbarh and Badraoui 2002; Daoud et al. 2016). The addition of biochar can be a solution as it has been highly reported to retain water and nutrients in soils.

According to our knowledge, no research to date has been carried out on the production and characterization of biochar produced from argan shells wastes. In this study, argan shells were selected as the biomass source for producing biochar. Argania, a genus of flowering plants contain the only species Argania spinosa, referred to as argan, a tree that grows in the Sous Area in Morocco. It has a small, oval, round or conical fruit, whose fleshy pulp is covered by a thick peel that surrounds a hard-shelled nut. The latter represents approximately $25 \%$ of the weight of the fresh fruit. Fruit size varies from 17 to $30 \mathrm{~mm}$ long and 10-17 mm wide. Converting of aragn hard-shelled into biochar can be an alternative way to dispose and recycle wastes.

\section{Materials and methods}

\section{Biochar preparation}

Argan shells obtained after the extraction of argan oil were used and converted into biochar. These materials are easily available in southwestern Morocco at relatively low price. For our current biochar research, we have used a pyrolytic stove fabricated in Morocco from locally available materials based on the design provided by Dr. Claudia Kammann (Institute for Plant Ecology, Giessen University, Germany). The pyrolysis stove which is produced from zinc alloy sheet has a cylindrical shape with a $40 \mathrm{~cm}$ height. It consists of different parts: a combustion chamber whose diameter is $18 \mathrm{~cm}$, an outer chamber with $28 \mathrm{~cm}$ diameter and a lid with ventilation tube.

First, we started the process of pyrolysis by filling the combustion chamber with fuel materials, which were used for lightening purposes. The argan shells are then placed in the gasifier space. Once the fire started burning, the lid was put on the stove. 20 min later, the flame became yellow which was a sign that the fuel material was burnt hotter. The argan shells biomass started to burn after $30 \mathrm{~min}$ at a slow pyrolysis temperature ranged between 300 and $500{ }^{\circ} \mathrm{C}$. Simultaneously the flame became blue releasing some smoke, which indicated that a complete burn of the fuel was reached. After $2 \mathrm{~h}$, the biomass was completely combusted. The resulting biochars ( $28 \%$ of the biomass) were then crushed and sieved to $2 \mathrm{~mm}$ particles to get a more homogenous substrate. So, the differences between the samples are minimized. The ash and moisture contents in argan schells biochar were 19.35 and $0.97 \%$, respectively. The organic matter content was $8.55 \%$ with $4.95 \%$ total organic carbon (Walkley-black method). The total N content was 150 ppm determined following the Kjeldahl method.

\section{Soil, peat and biochar analysis}

All physical and chemical analysis of the soil, peat and biochar were performed separately in the Hassan II Agronomic and Veterinary Institute (IAV) soil science laboratory using standard analytical methods. The biochar sample collected from the pyrolysis stove sieved $(<2 \mathrm{~mm})$, and its characteristics were analysed. The $\mathrm{pH}$ and electrical conductivity (EC) were both measured in water extracts with standard electrodes. For chemical analysis, the total concentration of $\mathrm{Na}, \mathrm{K}, \mathrm{Ca}$ and $\mathrm{Mg}$ were determined by flame emission spectrophotometer and $\mathrm{Fe}, \mathrm{Mn}, \mathrm{Zn}$ and $\mathrm{Cu}$ by atomic absorption spectrophotometer and colorimetrically for $\mathrm{NaNO}_{3}$ and $\mathrm{KH}_{2} \mathrm{PO}_{4}$.

\section{Water holding capacity}

Six biochar-fine sand mixtures have been prepared. We have used small amounts of biochar that equal $0,0.5,1,2$, 4 and $8 \%$, which means that $1 \%$ describes a mixture of $1 \mathrm{~g}$ dry biochar with $99 \mathrm{~g}$ dry sand. Around $40 \mathrm{~g}$ of fresh weight of each mixture were filled in small gray PE-tubes (height: $5,5 \mathrm{~cm}$; inner diameter: $3,6 \mathrm{~cm}$ ) that were closed at the bottom with gaze and filter paper. The filled tubes were placed in a plastic box that was then filled with tap water. The box was covered with aluminum foil. After $24 \mathrm{~h}$ the tubes were placed on test tube racks to let water drip out. $24 \mathrm{~h}$ later, the weight of the tubes were determined and the water content was calculated (knowing in advance the dry weight of the substrate). Then, the maximum water holding capacity can be determined.

\section{Results and discussion}

The physical and chemical properties of sandy soil, peat and argan shells biochar are shown in Table 1. The $\mathrm{pH}$ varied from 5.81 to 10.7 and was higher in biochar. The EC value was lower for the soil than for the other media and was higher for biochar. Mineral composition differed among the substrates. The cation concentrations except $\mathrm{Ca}$ were the highest with biochar and the lowest with soil while heavy metals contents were the highest with the soil and the lowest with biochar. The available $\mathrm{NaNO}_{3}$ and $\mathrm{KH}_{2} \mathrm{PO}_{4}$ were different in the three substrates. The $\mathrm{NaNO}_{3}$ and $\mathrm{KH}_{2} \mathrm{PO}_{4}$ content were the highest with peat. 
Table 1 Comparaison of physico-chemical characteristics of the used biochar with sandy-soil and peat

\begin{tabular}{llll}
\hline & Soil & Peat & Biochar \\
\hline $\mathrm{pH}$ & 7.93 & 5.81 & 10.7 \\
$\mathrm{EC}($ milliS cm & -1 & & \\
$\mathrm{~K}(\mathrm{ppm})$ & 0.48 & 0.94 & 4.83 \\
$\mathrm{Na}(\mathrm{ppm})$ & 7.11 & 78.26 & 1906.25 \\
$\mathrm{Ca}(\mathrm{ppm})$ & 3.47 & 257.94 & 339.2 \\
$\mathrm{Mg}(\mathrm{ppm})$ & 34.09 & 190.9 & 4.8 \\
$\mathrm{Fe}(\mathrm{ppm})$ & 222.89 & 1191.58 & 1258.92 \\
$\mathrm{Mn}(\mathrm{ppm})$ & 9.07 & 0 & 0 \\
$\mathrm{Cu}(\mathrm{ppm})$ & 7.7 & 0.14 & 0.04 \\
$\mathrm{Zn}(\mathrm{ppm})$ & 1.3 & 0.06 & 0 \\
$\mathrm{NaNO}_{3}(\mathrm{ppm})$ & 0.42 & 0.04 & 0.04 \\
$\mathrm{KH}_{2} \mathrm{PO}_{4}(\mathrm{ppm})$ & 100 & 133.33 & 100 \\
\hline
\end{tabular}

The pyrolysis conditions and the nature of the feedstock affect $\mathrm{pH}$ values which are documented to vary from 4 to 13 (Cheng et al. 2006; Chan et al. 2008). In this sense, biochar from argan shells reached the same $\mathrm{pH}$ range $(\mathrm{pH}$ 10). The same result of alkaline nature of biochar has previously been published (Novak et al. 2009). The alkaline nature of biochar has been reported to be beneficial to rise the $\mathrm{pH}$ of acidic soils.

The EC value was higher for biochar $(4.83 \mathrm{mS} / \mathrm{cm})$. Previous research reported that added biochar with high EC value into the soil with low EC value (indicating its low salinity) increased EC of soil (Chan et al. 2008). For biochar produced in this research, we would expect that the EC of the soil $(0.48 \mathrm{mS} / \mathrm{cm})$ would increase with biochar application. However, before adding biochar to soils and to avoid problems related to soil salinization and nutrient imbalances, the use of biochar should be carefully investigated. The presence of salts and alkaline cations in the biochar are responsible for the highly $\mathrm{pH}$ and $\mathrm{EC}$ values. Because of the higher relative solubility of $\mathrm{K}$ containing salts and carbonates in water, the $\mathrm{K}$ contents of the biochars can have an effect on EC values (Uras et al. 2012).

Furthermore, we have found that biochar had relatively high $\mathrm{K}$ and $\mathrm{Na}$ content (Table 1). Similar increases in $\mathrm{K}$ and $\mathrm{Na}$ content in biochar have been observed by $\mathrm{Xu}$ et al. (2013); Smider and singh (2014); Stella Mary et al. (2016). As reported by Uras et al. (2012); Smider and Singh (2014), the excessive addition of Ca to soil could hinder the use of $\mathrm{Mg}$ and $\mathrm{K}$ except if it is added to soils suffering from $\mathrm{Ca}$ deficiency. Thus, argan biochar which contains low content of $\mathrm{Ca}$ can be worth considering as a soil amendment. The $\mathrm{Mg}$ content was relatively higher in the argan shells biochar than $\mathrm{Ca}$ and $\mathrm{Na}$. It is reported that the chemical constituents of biochar are directly affected by different parameters: the temperature, the time and the heating rate during pyrolysis (Lima and Marshall 2005) which is in line with our result. In addition, biochar and soil showed the same value of $\mathrm{NaNO}_{3}$; whereas soil showed the higher value of $\mathrm{KH}_{2} \mathrm{PO}_{4}$ (Table 1). Biochars, as reported by Coates (2000), contain little or no $\mathrm{NO}_{3}{ }^{-}$, which is a basic nutrient for plant growth while the $\mathrm{PO}_{4}{ }^{3-}$ was characteristic for each feedstock (Uras et al. 2012).

However, many studies showed that biochar can be contaminated during pyrolysis process by dangerous inorganic substances (heavy metals) and organic ones (Hale et al. 2012; Oleszczuk et al. 2013; Buss and Masek 2014; Kołtowski and Oleszczuk 2015; Domene et al. 2015) which was not the case in our study where heavy metal contents were higher with soil and lower with biochar.

It has been demonstrated that the nature of feedstock and production conditions affect the chemical composition of biochar (Lima and Marshall 2005; Stella Mary et al. 2016). The physical and chemical properties of the argan shells biochar revealed a highly alkaline $\mathrm{pH}$, high electrical conductivity (EC), high content of $\mathrm{K}, \mathrm{Na}, \mathrm{Mg}$ and $\mathrm{NaNO}_{3}$, low content of $\mathrm{Ca}, \mathrm{KH}_{2} \mathrm{PO}_{4}$ and low content of heavy metals compared to sandy soil and peat. So, due to its high nutrient content and low content of heavy metals, argan biochar can improve plant growth especially in the sandy soil.

The water holding capacities (WHC) were 0.36, 0.39, $0.40,0.41,0.41$ and $0.43 \mathrm{gH} 2 \mathrm{O} \mathrm{g}^{-1}$ soil (dry weight) in $0 \%$, $0.5 \%$ (the lowest rate application), 1, 2, 4 and $8 \%$ (the highest rate application), respectively. The biochar application increased the WHC by $7.69 \%$ in $0.5 \%$ and $16.28 \%$ in $8 \%$ compared to the control. An increase in water holding capacity has also been reported with biochar application (Abel et al. 2013; Andrenellia et al. 2016; Stella Mary et al. 2016). Thus, agran shells biochar will be beneficial to the soil where there is less drainage.

\section{Conclusion}

In semi-arid, arid and desert climatic conditions, like the case of Morocco, the agricultural practices reserve a majority of the water resources to be used for irrigation. The extent of irrigated agriculture combined with high evaporative rates, lead to degradation of soil quality. The soil deterioration can be remedied using biochar which is highly considered to improve the physical, chemical and biological soil characteristics.

In this study, analysis of biochar from argan shells indicated that it contains more major nutrients and less heavy metals than the sandy soil and peat. When used in mixture with sandy soil, it increases the water holding capacity. Due to these properties, biochar can be used as an alternative soil amendment. However, future research should consider changes in nutrient availability and plant growth. 
Acknowledgements This work has been funded by the Hassan II Agronomic and Veterinary Institute, Agadir, Morocco. L. Bouqbis would like to acknowledge Mr. Mohamed DOULHOUSNE for his contribution to experimental work.

Open Access This article is distributed under the terms of the Creative Commons Attribution 4.0 International License (http://crea tivecommons.org/licenses/by/4.0/), which permits unrestricted use, distribution, and reproduction in any medium, provided you give appropriate credit to the original author(s) and the source, provide a link to the Creative Commons license, and indicate if changes were made.

\section{References}

Abel S, Peters A, Trinks S, Schonsky H, Facklam M, Wessolek G (2013) Impact of biochar and hydrochar addition on water retention and water repellency of sandy soil. Geoderma 202:183-191. doi:10.1016/j.geoderma.2013.03.003

Andrenellia MC, Maienzab A, Genesiob L, Migliettab F, Pellegrinia S, Vaccarib FP, Vignozzia N (2016) Field application of pelletized biochar: short term effect on the hydrological properties of a silty clay loam. Agric Water Manag 163:190-196. doi:10.1016/j.agwat.2015.08.023

Badraoui M, Agbani M, Soudi B (2000) Evolution de la qualité des sols sous mise en valeur intensive au Maroc. Séminaire 'Intensification agricole et qualité des sols et des eaux', Rabat, Maroc, 2-3 Novembre 2000

Buss W, Masek O (2014) Mobile organic compounds in biochar: a potential source of contamination-phytotoxic effects on cress seed (Lepidium sativum) germination. J Environ Manage 137:111-119. doi:10.1016/j.jenvman.2014.01.045

Cao CTN, Farrella C, Kristiansenc PE, Rayner JP (2014) Biochar makes green roof substrates lighter and improves water supply to plants. Ecol Eng 71:368-374. doi:10.1016/j.ecoleng.2014.06.017

Chan KY, Zwieten LV, Meszaros I, Downie A, Joseph S (2008) Using poultry litter biochars as soil amendments. Aust J Soil Res 46:437-444. doi:10.1071/SR08036

Cheng CH, Lehmann J, Thies JE, Burton SD, Engelhard MH (2006) Oxidation of black carbon by biotic and abiotic processes. Org Geochem 37:1477-1488. doi:10.1016/j.orggeochem.2006.06. 022

Coates J (2000) Interpretation of infrared spectra, a practical approach, in: Encyclopedia of Analytical Chemistry. John Wiley and Sons Ltd., USA, pp, 10815-10837

Daoud S, Elbrik K, Tachbibi N, Bouqbis L, Brakez M, and Harrouni MC (2016) The potential use of halophytes for the development of marginal dry areas in Morocco. In: Muhammad Ajmal Khan, Munir Ozturk, Bilquees Gul, Muhammad Zaheer Ahmed (eds) Halophytes for food security in dray lands. Elsevier Inc, Amsterdam, pp 141-156. ISBN: 978-0-12-801854-5

Debbarh A, Badraoui M (2002) Irrigation et environnement au Maroc: Situation actuelle et perspectives. Serge Marlet et Pierre Ruelle (éditeurs scientifiques). Vers une maîtrise des impacts environnementaux de l'irrigation. Actes de l'atelier du PCSI, 28-29 mai 2002, Montpellier, France. CEMAGREF, CIRAD, IRD, Cédérom du CIRAD

Domene X, Enders A, Hanley K, Lehmann J (2015) Ecotoxicological characterization of biochars: role of feedstock and pyrolysis temperature. Sci Total Environ 512-513:552-561. doi:10.1016/j. scitotenv.2014.12.035

Hale SE, Lehmann J, Rutherford D, Zimmerman AR, Bachmann RT, Shitumbanuma V, O'Toole A, Sundqvist KL, Arp HPH, Cornelissen G (2012) Quantifying the total and bioavailable polycyclic aromatic hydrocarbons and dioxins in biochars. Environ Sci Technol 46:2830-2838. doi:10.1021/es203984k

Hossain MK, Strezov V, Chan KY, Nelson PF (2010) Agronomic properties of wastewater sludge biochar and bioavailability of metals in production of cherry tomato (Lycopersicon esculentum). Chemosphere 78:1167-1171. doi:10.1016/j.chemosphere. 2010.01.009

Jiang X, Denef K, Stewart CE, Cotrufo MF (2016) Controls and dynamics of biochar decomposition and soil microbial abundance, composition, and carbon use efficiency during long-term biochar-amended soil incubations. Biol Fertil Soils. doi:10.1007/ s00374-015-1047-7

Kammann CI, Linsel S, Gößling JW, Werner Koyro HW (2011) Influence of biochar on drought tolerance of Chenopodium quinoa willd and on soil-plant relations. Plant Soil 345:195-210. doi:10.1007/s11104-011-0771-5

Kaudal BB, Chen D, Madhavan DB, Downie A, Weatherley A (2016) An examination of physical and chemical properties of urban biochar for use as growing media substrate. Biomass Bioenergy 84:49-58. doi:10.1016/j.biombioe.2015.11.012

Kołtowski M, Oleszczuk P (2015) Toxicity of biochars after polycyclic aromatic hydrocarbons removal by thermal treatment. Ecol Eng 75:79-85. doi:10.1016/j.ecoleng.2014.11.004

Laird DA, Fleming P, Davis DD, Horton R, Wang BQ, Karlen DL (2010) Impact of biochar amendments on the quality of a typical Midwestern agricultural soil. Geoderma 158:443-449. doi:10. 1016/j.geoderma.2010.05.013

Lehmann J, Gaunt J, Rondon M (2006) Bio-char sequestration in terrestrial ecosystems-a review. Mitig Adapt Strat Glob Change 11:403-427. doi:10.1007/s11027-005-9006-5

Lima IM, Marshall WE (2005) Granular activated carbons from broiler manure: physical, chemical and adsorptive properties. Biores Techno 96(6):699-706. doi:10.1016/j.biortech.2004.06. 021

Liu S, Ahlm L, Day DA, Russell LM, Zhao Y, Gentner DR, Weber RJ, Goldstein AH, Jaoui M, Offenberg JH, Kleindienst TE, Rubitschun C, Surratt JD, Sheesley RJ, Scheller S (2012) Secondary organic aerosol formation from fossil fuel sources contribute majority of summertime organic mass at Bakersfield. J Geophys Res 117:D00V26. doi:10.1029/2012JD018170

Liu X, Liu MD, Gao ZG, Yang D (2013) Effect of different biochars on yield and yield components of wheat on different soils. Adv Mater Res 726-731:2665-2669. doi:10.4028/www.scientific.net/ AMR.726-731.2665

Novak JF, Busscher WJ, Laird DL, Ahmedna M, Watts DW, Niandou MAS (2009) Impact of biochar amendment on fertility of a Southeastern coastal plain soil. Soil Sci 174:105-112. doi:10. 1097/SS.0b013e3181981d9a

Oleszczuk P, Jo sko I, Ku smierz M (2013) Biochar properties regarding to contaminants content and ecotoxicological assessment. J Hazard Mater 260:375-382. doi:10.1016/j.jhazmat.2013. 05.044

Romanyà J, Rovira P (2011) An appraisal of soil organic C content in Mediterranean agricultural soils. Soil Use Manage 27:321-332. doi:10.1111/j.1475-2743.2011.00346.x

Smider B, Singh B (2014) Agronomic performance of a high ash biochar in two contrasting soils. Agric Ecosyst Environ 191:99-107. doi:10.1016/j.agee.2014.01.024

Stella Mary G, Sugumaran P, Niveditha S, Ramalakshmi B, Ravichandran P, Seshadri S (2016) Production, characterization and evaluation of biochar from pod (Pisum sativum), leaf (Brassica oleracea) and peel (Citrus sinensis) wastes. International Journal of Recycling of Organic Waste in Agriculture 5:43-53. doi:10.1007/s40093-016-0116-8

Tammeorg P, Simojokib A, Mäkelä P, Stoddard FL, Alakukku L, Helenius J (2014) Short-term effects of biochar on soil properties 
and wheat yield formation with meat bone meal and inorganic fertiliser on a boreal loamy sand. Agric Ecosyst Environ 191:108-116. doi:10.1016/j.agee.2014.01.007

Uras Ü, Carrier M, Hardie AG, Knoetze JH (2012) Physico-chemical characterization of biochars from vacuum pyrolysis of South African agricultural wastes for application as soil amendments. J Anal Appl Pyrol 98:207-213. doi:10.1016/j.jaap.2012.08.007
Xu G, Wei LL, Sun JN, Shao HB, Chang SX (2013) What is more important for enhancing nutrient bioavailability with biochar application into a sandy soil: direct or indirect mechanism? Ecol Eng 52:119-124. doi:10.1016/j.ecoleng.2012.12.091 